\title{
SULPHUR CONTENT IN TEST PLANTS AND ARYLSULFATASE ACTIVITY IN SOIL AFTER APPLICATION OF WASTE MATERIALS
}

\author{
GODLEWSKA, A. \\ Siedlce University of Natural Sciences and Humanities, Faculty of Natural Science \\ B. Prusa 12 st., 08-110 Siedlce, Poland \\ e-mail:agnieszka.godlewska@uph.edu.pl \\ (Received $3^{\text {rd }}$ Aug 2017; accepted $27^{\text {th }}$ Oct 2017)
}

\begin{abstract}
Sulphur available for plants may come from organic compounds introduced to the soil with waste materials which undergoes arylsulfatase-assisted mineralisation. Studies were undertaken to assess the effect of fertilisation with sewage sludge and hard coal ash on sulphur content and uptake by test plants, and arylsulfatase activity in the soil. The experimental design was a completely randomised arrangement with three replicates. The following factors were examined: I fertilisation with organic and mineral materials: fresh sewage sludge, hard coal ash, calcium carbonate; II mineral fertilisation: no fertilisation; NPK fertilisation. The sulphur content in orchard grass was significantly higher following an application of composted sewage sludge and hard coal ash, and in maize after an application of sludge/ash mixtures. The waste materials and NPK fertilisation significantly increased sulphur uptake by both the plants tested. Arylsulfatase activity was significantly higher in fresh sludge-amended soil compared with the remaining amended units whereas an application of ash reduced the activity of the enzyme. NPK fertilisation had no significant influence on the enzyme studied.
\end{abstract}

Keywords: sewage sludge, hard coal ash, manure, orchard grass, maize, enzyme

\section{Introduction}

Sulphur is widely found in nature as it takes part in life processes occurring in all living organisms and determines their proper functioning. Sulphur deficiency leads to a decline in plant protein, which contributes to a decline in yield quantity and quality (Millard et al., 2006). Soil sulphur has been on the decline in recent years due to an introduction of restrictions on sulphur dioxide amounts released into the atmosphere (Scherer, 2009), an application in cultivation of high-yielding cultivars and highlyconcentrated mineral fertilisers, and a drop in farmyard manure production. Organic compounds in manures obtained from natural waste materials may be a source of plantavailable elements, including sulphur (Ciepiela et al., 2016). The fertilisers include sewage sludge which, when introduced into the soil, undergoes arylsulfatase-assisted mineralisation. The enzyme is abundant in the soil as it takes part in the processes of oxidation of sulphur which it available for plants (Siwik-Ziomek et al., 2013). Waste materials are a valuable source of nutrients (Farasat and Namli, 2016), including sulphur which, in addition to nitrogen is the main factor determining soil fertility and hence its productive potential. It is worth considering the possibility of using sewage sludge and ashes emitted by power plants in crop fertilisation as they contain considerable amounts of sulphur (Kalembasa et al., 2008) which, however, occurs in various forms, some of them being unavailable for crop plants. When introduced into the soil, these waste materials may improve the nutrient balance in the environment (Palumbo et al., 2007; Antonkiewicz, 2010) and, at the same time, limit the effect of their excess concentration in the place where they are stored, thus solving the problem of their utilisation (Bernoud et al., 2016). 
Studies were undertaken to assess the effect of fertilisation with sewage sludge and hard coal ash on sulphur content and uptake by test plants, and arylsulfatase activity in the soil.

\section{Materials and methods}

A pot experiment was established in a glasshouse located at the experimental unit of Siedlce University of Natural Sciences and Humanities in Poland in 2007-2008. The experimental design was a completely randomised arrangement with three replicates. The following factors were examined:

I. fertilisation with organic and mineral materials:

a) fresh sewage sludge;

b) sludge obtained from the sewage treatment works in Siedlce and composted for three months (industrial and domestic waste water);

c) hard coal ash obtained from the electricity distribution company in Siedlce;

d) calcium carbonate.

Sewage sludge was applied once, adding 5\% relative to soil weight. Sewage sludge and coal ash were mixed at the ratio of $2: 1$ when converted to dry matter.

II. mineral fertilisation:

a) no fertilisation;

b) NPK fertilisation.

Mineral fertilisers: urea, triple superphosphate and potassium sulphate, were applied pre-plant. The soil used in the experiment was very loamy sand obtained from the 0-20 $\mathrm{cm}$ layer of grey brown podzolic soil. Before the experiment was set up, soil contents of nitrogen, carbon, available phosphorus and potassium were determined (respectively: $1.10,8.20,0.052$ and $0.071 \mathrm{~g} \mathrm{~kg}^{-1}$ ). Pots were filled with $10 \mathrm{~kg}$ of soil and kept during the growing season at the moisture level of $60 \%$ maximum water holding capacity of the soil.

Orchard grass (Dactylis glomerata) was tested in the first study year. It was sown at $1.0 \mathrm{~g} \mathrm{pot}^{-1}$ and harvested three times during the growing season. In the second year, maize was grown at a density of 3 plants per pot. After harvest, plants were dried and ground to determine the total sulphur content by ICP - AES after dry mineralisation. The plant material was incinerated in a muffle furnace at $450^{\circ} \mathrm{C}$, temperature being increased gradually, and $\mathrm{HCl}$ solution (1:1) was added to mineralised samples which were then evaporated to dryness in order to decompose carbonates and precipitate silica. $10 \% \mathrm{HCl}$ was added to the resultant crude ash which was moved to volumetric flasks by pouring it through a hard filter paper. The total sulphur content in sewage sludge and hard coal ash were determined by ICP-AES following mineralisation of material to dryness. Arylsulfatase activity was determined by colorimetry of $p$-nitrophenol released when soil samples were incubated one hour at $37^{\circ} \mathrm{C}$ with $p$-nitrophenyl sulfate (Tabatabai and Bremner, 1970). All colorimetric data was determined with a spectrophotometr UV-VIS Lambda 25 (Perkin Elmer, Whaltham, USA).

The program STATISTICA (data analysis software system), version 12 (www.statsoft.com) was used to statistically analyse the results. Significance of differences between means for the experimental factors were checked using Tukey's test at the significance level of $\alpha \leq 0.01$. 


\section{Results and discussion}

In addition to nitrogen and phosphorus, sulphur is an element which markedly affects crop yields. Sulphur content in sewage sludge and hard coal ash used in this experiment was, respectively, 8.47 and $5.45 \mathrm{~g} \mathrm{~kg}^{-1}$ in d.m. This high sulphur content in sewage sludge and coal ash is several times higher compared with farmyard manure (Kalembasa and Godlewska, 2010).

Sulphur content in the biomass of orchard grass in the first study year (Table 1) was affected by all the experimental factors and averaged $3.46 \mathrm{~g} \mathrm{~kg}^{-1} \mathrm{~d} . \mathrm{m}$. Such an amount of sulphur is believed to be high from the standpoint of livestock nutritional needs (Falkowski, 2000). An application of either fresh or composted sewage sludge reduced sulphur content in orchard grass compared with the control grass. The fact can be indicative of an occurrence in sewage sludge of barely soluble sulphur forms which are unavailable for plants and undergo mineralisation in the soil. An application of hard coal ash increased sulphur content in control plants and sludge-manured plants. However, significant differences in sulphur content were found between plants harvested from hard coal ash-manured plots and plants manured with composted sewage sludge. An addition of ash to composted sludge contributed to an increase in sulphur content in orchard grass biomass. NPK fertilisation only slightly increased sulphur content in the plants tested but the differences were not statistically significant.

Table 1. The content of $S$ (in $g \mathrm{~kg}^{-1} \mathrm{DM}$ ) in orchard grass

\begin{tabular}{|c|c|c|c|c|c|c|c|c|c|}
\hline \multicolumn{2}{|l|}{ NPK fertilization } & \multicolumn{3}{|c|}{$\mathbf{0}$} & \multicolumn{4}{|c|}{ NPK } & \multirow{2}{*}{ Mean } \\
\hline $\begin{array}{l}\text { Organic and } \\
\text { mineral materials }\end{array}$ & $\mathbf{I}$ & II & III & Mean & $\mathbf{I}$ & II & III & Mean & \\
\hline control object & 3.90 & 3.21 & 3.83 & 3.65 & 3.98 & 3.21 & 3.86 & 3.68 & $3.67 \mathrm{bcd}$ \\
\hline sewage sludge & 2.86 & 3.18 & 4.00 & 3.35 & 3.57 & 3.01 & 4.38 & 3.65 & $3.50 \mathrm{abcd}$ \\
\hline composted sewage sludge & 3.26 & 2.91 & 3.84 & 3.34 & 3.32 & 2.68 & 2.72 & 2.91 & $3.12 \mathrm{ab}$ \\
\hline hard coal ash & 3.90 & 3.35 & 3.35 & 3,60 & 4.70 & 3.84 & 3.98 & 4.17 & $3.85 \mathrm{~cd}$ \\
\hline sewage sludge/ash & 2.09 & 2.66 & 3.59 & 3.04 & 4.16 & 2.79 & 3.77 & 3.57 & $3.18 \mathrm{abc}$ \\
\hline composted sewage sludge/ash & 3.38 & 3.51 & 4.38 & 4.76 & 3.09 & 2.80 & 4.64 & 3.51 & $3.63 \mathrm{bcd}$ \\
\hline liming & 4.74 & 3.78 & 3.96 & 4.16 & 5.42 & 2.85 & 3.26 & 3.84 & $4.00 \mathrm{~d}$ \\
\hline liming/sewage sludge/ash & 2.89 & 2.13 & 3,18 & 2.73 & 4.06 & 2.07 & 2.95 & 3.03 & $2.88 \mathrm{a}$ \\
\hline $\begin{array}{l}\text { liming /composted sewage } \\
\text { sludge/ash }\end{array}$ & 2.70 & 2.76 & 3.70 & 3.05 & 3.78 & 2.07 & 4.68 & 3.51 & $3.28 \mathrm{abc}$ \\
\hline Mean & 3.30 & 3.05 & 3.76 & 3.37 & 4.01 & 2.81 & 3.80 & 3.54 & 3.46 \\
\hline
\end{tabular}

a,b,c,d - groups of means which do not differ significantly at $\alpha<0.01$

Maize needs average amounts of sulphur but it produces high dry matter content so it requires intensive fertilisation. Maize cultivated in the second study year (Table 2) contained on average 1.02 sulphur per $\mathrm{kg}^{-1} \mathrm{~d} . \mathrm{m}$. The organic materials and coal ash 
markedly influenced the plant content of sulphur. The effect of fertilisation with sewage sludge was visible in the second study year, which can indicate that the sludge organic compounds underwent mineralisation and sulphur was transformed into forms available for plants. Nutrients in sewage sludge occur mainly in organically-bound forms, which means they are available only when these materials have undergone mineralisation (Fijałkowski and Kacprzak, 2009). The biomass of maize harvested from sewage sludge-amended units and sewage/coal ash-amended units contained significantly more sulphur compared with control plants. Research conducted by Gondek (2010a) demonstrated that plant biomass content of sulphur increased following an application of sewage sludge. Also Gondek and Filipek-Mazur (2008) reported a significant increase in sulphur content in the biomass of sewage sludge/peat-fertilised maize. An addition of hard coal ash to composted sewage sludge contributed to an increase in the plant biomass content of sulphur but the differences were not substantial, which seems obvious as the mineral fertilisers that had been applied contained sulphur (triple superphosphate and potassium sulphate).

Table 2. The content of $S$ (in $\mathrm{kg}^{-1} \mathrm{DM}$ ) in maize

\begin{tabular}{lccc} 
& & & \\
and mineral materials & $\mathbf{0}$ & NPK & Mean \\
\hline control object & & & \\
sewage sludge & 0.620 & 0.858 & $0.739 \mathrm{a}$ \\
composted sewage sludge & 0.820 & 1.52 & $1.17 \mathrm{~cd}$ \\
hard coal ash & 0.705 & 1.25 & $0.978 \mathrm{bc}$ \\
sewage sludge/ash & 0.615 & 1.28 & $0.948 \mathrm{ab}$ \\
composted sewage sludge/ash & 0.760 & 1.30 & $1.03 \mathrm{bcd}$ \\
liming & 0.890 & 1.35 & $1.12 \mathrm{bcd}$ \\
liming/sewage sludge/ash & 0.828 & 1.09 & $0.959 \mathrm{abc}$ \\
liming/composted sewage sludge/ash & 1.01 & 1.43 & $1.22 \mathrm{~d}$ \\
\hline \multicolumn{1}{c}{ Mean } & 0.98 & 1.07 & $1.03 \mathrm{bcd}$ \\
\hline
\end{tabular}

See explanation in Table 1

Sulphur uptake by plants in the first study year differed and depended on the waste materials applied (Table 3). Statistical analysis demonstrated that sulphur uptake by plants was significantly higher following an application sewage sludge (fresh and composted) and its mixture with hard coal ash. Sulphur uptake was the highest after an application of composted sewage sludge and hard coal ash, the increase being over $140 \%$ compared with control plants. Also grasses grown in pots where only liming or hard coal ash had been applied took up more sulphur compared with control but the differences were insignificant. Hard coal ash is a waste material which contains substantial amounts of calcium and magnesium (Kalembasa et al., 2008), which might contribute to an increase in sulphur uptake by plants. Moreover, a tendency was 
observed for orchard grass to take up less sulphur in successive cuts. However, in pots without NPK fertilisation where soil had been amended with sewage sludge and its mixture with coal ash, sulphate uptake was the highest in the second cut. The fact can indicate how fast the rate of mineralisation was.

Table 3. The total sulphur uptake ( $m g$ pot $^{-1}$ ) by orchard grass

\begin{tabular}{|c|c|c|c|c|c|c|c|c|c|}
\hline NPK fertilization & & & $\mathbf{0}$ & & & & PK & & \\
\hline $\begin{array}{l}\text { Organic } \\
\text { and mineral materials }\end{array}$ & $\mathbf{I}$ & II & III & Mean & $\mathbf{I}$ & II & III & Mean & Mean \\
\hline control object & 31.2 & 13.9 & 12.2 & 19.1 & 19.5 & 10.9 & 23.5 & 18.0 & $18.5 \mathrm{a}$ \\
\hline sewage sludge & 48.3 & 54.4 & 45.6 & 49.4 & 32.6 & 49.7 & 29.5 & 37.3 & $43.4 b$ \\
\hline composted sewage sludge & 47.3 & 49.8 & 32.3 & 43.1 & 24.3 & 43.4 & 30.2 & 32.6 & $37.9 b$ \\
\hline hard coal ash & 34.6 & 14.6 & 8.81 & 19.3 & 63.5 & 50.3 & 14.4 & 42.7 & $31.0 \mathrm{ab}$ \\
\hline sewage sludge/ash & 26.2 & 43.6 & 39.1 & 36.3 & 49.9 & 46.2 & 32.4 & 42.8 & $39.6 b$ \\
\hline composted sewage sludge + ash & 49.1 & 59.6 & 36.8 & 48.5 & 62.0 & 33.2 & 27.2 & 40.8 & $44.7 b$ \\
\hline liming & 53.7 & 19.8 & 26.3 & 33.3 & 77.0 & 17.8 & 5.97 & 33.6 & $33.4 \mathrm{ab}$ \\
\hline liming/sewage sludge/ash & 31.3 & 18.4 & 18.8 & 22.8 & 74.7 & 40.2 & 24.9 & 46.6 & $34.7 b$ \\
\hline $\begin{array}{l}\text { liming/composted sewage } \\
\text { sludge/ash }\end{array}$ & 35.6 & 35.2 & 30.3 & 33.7 & 64.6 & 35.1 & 28.1 & 42.6 & $38.2 b$ \\
\hline Mean & 39.7 & 34.3 & 27.8 & $33.9 \mathrm{a}$ & 52.0 & 36.3 & 24.0 & $37.4 \mathrm{a}$ & 35.7 \\
\hline
\end{tabular}

See explanation in Table 1

Analysis of data revealed that mineral (NPK) fertilisation had an insignificant effect on sulphur uptake by orchard grass.

In the second study year, differences in sulphur uptake by maize remained significant (Table 4). An application of hard coal ash increased sulphur uptake by maize compared with control, the differences being insignificant. A significantly lower amount of sulphur was taken up by control maize compared with plants grown in all the remaining experimental units. However, the greatest increase in sulphur uptake by maize (by almost $130 \%$ compared with control) was observed in fresh sewage sludge-amended units. Liming increased sulphur uptake by plants, which agrees with findings reported by Gondek (2010b). NPK fertilisation increased sulphur uptake by maize by $239 \%$, the differences being significant.

Arylsulfatase activity in the soil studied (Table 5) averaged $18.5 \mu \mathrm{g}$ PNP g $\mathrm{g}^{-1} \mathrm{~h}^{-1}$. Koper and Siwik-Ziomek (2004) obtained similar results ranging from 16.9 to $30.8 \mu \mathrm{g}$ PNP $\mathrm{g}^{-1} \mathrm{~h}^{-1}$, for soils amended with farmyard manure and NPK. According Balota and Chaves (2010), arylsulfatase activity cited in literature varies widely from 4 to $770 \mu \mathrm{g}$ PNP g ${ }^{-1} \mathrm{~h}^{-1}$ and depending on different factors. Statistical analysis demonstrated a varied significant effect of waste materials on arylsulfatase activity in the soil. The greatest increase in the activity of the enzyme (by 33.9\%) was found in soil amended with fresh sewage sludge compared with the control. The findings confirm that organic matter significanly affects enzyme activity (Bielińska and Mocek-Płóciniak, 2009; 
Siwik-Ziomek and Lemanowicz, 2014). When carbon compounds are present, they stimulate the biosynthesis ofenzymes by soil microrgansims so fresh organic matter incorporated into the soil in the form of sewage sludge significantly increased arylsulfatase in the soil studied.

Table 4. The total sulphur uptake $\left(m g\right.$ pot $\left.^{-1}\right)$ by maize

\begin{tabular}{lccc}
\hline & & & \\
and mineral materials & $\mathbf{0}$ & NPK & Mean \\
\hline control object & & & \\
sewage sludge & 14.8 & 75.7 & $45.3 \mathrm{a}$ \\
composted sewage sludge & 47.6 & 158 & $102.8 \mathrm{c}$ \\
hard coal ash & 33.0 & 101 & $67.0 \mathrm{~b}$ \\
sewage sludge/ash & 20.1 & 104 & $62.1 \mathrm{ab}$ \\
composted sewage sludge/ash & 50.2 & 102 & $76.1 \mathrm{~b}$ \\
liming & 38.9 & 113 & $76.0 \mathrm{~b}$ \\
liming/sewage sludge/ash & 21.2 & 121 & $71.1 \mathrm{~b}$ \\
liming/composted sewage sludge/ash & 37.6 & 124 & $80.8 \mathrm{~b}$ \\
\hline \multicolumn{1}{c}{ Mean } & 33.6 & 111 & $72.3 \mathrm{~b}$ \\
\hline
\end{tabular}

See explanation in Table 1

Table 5. Aryslulfatase activity in soil $\left(\mu \mathrm{g} P N P g^{-1} h^{-1}\right)$

\begin{tabular}{lccc} 
& & & \\
and mineral materials & $\mathbf{0}$ & NPK & Mean \\
\hline control object & & & \\
sewage sludge & 13.8 & 24.5 & $19.2 \mathrm{~cd}$ \\
composted sewage sludge & 27.1 & 24.3 & $25.7 \mathrm{e}$ \\
hard coal ash & 16.6 & 15.8 & $16.2 \mathrm{bc}$ \\
sewage sludge/ash & 17.3 & 7.00 & $12.2 \mathrm{ab}$ \\
composted sewage sludge/ash & 10.1 & 10.0 & $10.1 \mathrm{a}$ \\
liming & 17.6 & 13.0 & $15.3 \mathrm{abc}$ \\
liming/sewage sludge/ash & 19.5 & 21.0 & $20.3 \mathrm{cde}$ \\
liming/composted sewage sludge/ash & 21.4 & 23.2 & $22.3 \mathrm{de}$ \\
\multicolumn{1}{c}{ Mean } & 25.8 & 24.2 & $25.0 \mathrm{e}$ \\
\hline
\end{tabular}

See explanation in Table 1 
An application of hard coil ash and its addition to fresh and composted sewage sludge reduced soil enzymatic activity compared with control. Soil liming increased arylsulfatase activity in the soil but the differences were insignificant. According Bielinska and Baran (2009) that an addition of fluidal ashes from hard coal increased the enzymatic activity. Mineral fertilisation only slightly reduced arylsulfatase activity in the soil, which may be indicative of an inhibitory effect of mineral fertilisers on the activity of the enzyme, which has been confirmed by other authors, too (Siwik-Ziomek and Koper, 2008). Vong et al. (2004) has pointed out that high rates of nitrogen fertilisation contribute to a decline in soil enzymatic activity. Also Sun et al. (2016) observed sufficient $N$ increased the enzyme activity, but excess $\mathrm{N}$ did not stimulate activity.

In the present work, the linear correlation coefficient was calculated for the comparison between sulphur content and uptake by the biomass of maize and orchard grass harvested in individual cuts. The correlation (mean values) between these parameters determined in orchard grass biomass was significant and positive for the first cut only and amounted to $r=0.54^{* *}$. The value of the coefficient of linear correlation between sulphur content and uptake in maize biomass was $r=0.89^{* * *}$.

\section{Conclusions}

The sulphur content in orchard grass was significantly higher following an application of composted sewage sludge and hard coal ash, and in maize after an application of sludge/ash mixtures. The waste materials and NPK fertilisation significantly increased sulphur uptake by both the plants tested. Arylsulfatase activity was significantly higher in fresh sludge-amended soil compared with the remaining amended units whereas an application of ash reduced the activity of the enzyme. NPK fertilisation had no significant influence on the enzyme studied.

In summary, it should be noted that the degree of organic matter decomposition and origin has a considerable effect on the characteristics discussed in the work. Further studies are needed to develop more comprehensive results and evaluate the impact of different rates of organic and mineral materials.

\section{REFERENCES}

[1] Antonkiewicz, J. (2010): Effect of sewage sludge and furnace waste on the content of selected ele ments in the sward of legume-grass mixture. - Journal of Elementology 15(3): 435-443.

[2] Balota, E.L., Caves, J.C.D. (2010): Enzimatic activity mineralization of carbon and nitrogen in soil cultivated with coffee and green manures. - Revista Brasileira Ciência do Solo 34(5): 1573-1583. http://dx.doi.org/10.1590/S0100-06832010000500010

[3] Bernoud, F., Bernoud, M.A., Hachemi, M. (2016): Seasonal characterisation of the local sewage sludge. - Fresenius Environmental Bulletin 25(4): 1175-1182.

[4] Bielińska, J., Baran, S. (2009): Assessment concerning usability of fluidal ashes from hard coal for agricultural purposes. - Agricultural Engineering 6(115):7-15. (In Polish) (abstract in English)

[5] Bielińska, J., Mocek-Płóciniak, A. (2009): Impact of uncontrolled waste dumping on soil chemical and biochemical properties. - Archives of Environmental Protection 35(3): 101-107.

[6] Ciepiela, G.A., Godlewska, A., Jankowska, J. (2016): The effect of seaweed Ecklonia maxima and mineral nitrogen on fodder grass chemical composition. - Environmental Science and Pollution Research 23: 2301-2307. doi: 10.1007/s11356-015-5417-3. 
[7] Falkowski, M., Kukułka, I., Kozłowski, S. (2000): Chemical properties of meadow plants. Publisher. AR Poznań, 132pp. (In Polish)

[8] Farasat, S., Namli, A. (2016): Evaluating effects of sewage sludge on soil biochemical properties amounts (incubation experiment). - Fresenius Environmental Bulletin 25(5): 14841493.

[9] Fijałkowski, K., Kacprzak, M. (2009): The Influence of Sewage Sludge Addition on Selected Physico-Chemical Parameters of Degraded Soils. - Engineering and Protection of Environment 12(2): 133-141.

[10] Gondek, K. (2010a): Assessment of the influence of sewage sludge fertilizationon yield and content of nitrogenand sulphur in maize (Zea mays L.). - Journal of Elementology 15(1): 65-79.

[11] Gondek, K. (2010b): Assesment of the effect of sulphur supplied to the soil with mineral fertilizers and waste from magnesium sulphate production on its content in spring wheat (Triticum aestivum L.). - Acta Agrophysica 15(2): 269-280.

[12] Gondek, K., Filipek-Mazur, B. (2008): Changes of sulphur content in maize fertilized with organic materials. - Acta Agrophysica 11(3): 633-646. (In Polish) (abstract in English)

[13] Kalembasa, S., Godlewska, A. (2010): Total sulfur and its fractions as well as activity of arylsulfatase in soil depending on waste organic materials and liming. - Environmental Protection Engineering 36: 5-11.

[14] Kalembasa, S., Godlewska, A., Wysokiński, A. (2008): The chemical composition of ashes from brown coal and hard coal in the context of their agricultural utilization. - Soil Science Annual 59(2): 93-97.

[15] Koper, J., Siwik-Ziomek, A. (2004): Influence of long-term organic and mineral fertilization on the content of sulphur and arylosulphatase activity in soil. - Annales UMCS (Sec. E.) LIX (2): 671-678. (In Polish) (abstract in English)

[16] Millard, P., Gordon, A.H., Richardson, A.J., Chesson, A. (2006): Reduce ruminai degradation of ryegrass caused sulphur limitation. - Journal of Science Food and Agriculture 40: 305-314.

[17] Palumbo, A.V., Tarver, J.R., Fagan, L.A., McNeilly, M.S., Ruther, R., Fisher, L.S., Amonette, J.E. (2007): Comparing metal leaching and toxicity from high $\mathrm{pH}$, low $\mathrm{pH}$, and high ammonia fly ash. - Fuel 86: 1623-1630.

[18] Scherer, H.W. (2009): Sulfur in soils. - Journal of Plant Nutrition and Soil Science 172: 326-335.

[19] Siwik-Ziomek, A., Koper, J. (2008): Arylsulphatase activity and sulphur content in a soil after modification of fertilization. - Soil Science Annual LIX(1): 198-202.

[20] Siwik-Ziomek, A., Lemanowicz, J. (2014): The content of carbon, nitrogen, phosphorus and sulphur in soil against the activity of selected hydrolases as affected by crop rotation and fertilisation. - Zemdirbyste-Agriculture 101(4): 367-372. doi: 10.13080/z-a.2014.101.04

[21] Siwik-Ziomek, A., Lemanowicz, J., Koper, J. (2013): Arylsulphatase activity and the content of total sulphur and its forms under the influence of fertilisation with nitrogen and other macroelements. - Journal of Elementology 18(3): 437-447. doi: 10.5601/jelem.2013.18.3.08

[22] Sun, J., Ma, J., Zhu, M., Yuan, Z., Yao, J. (2016): Effects of nitrogen application on the soil microbial activity, enzyme activities and properties and their relationships in a maize field. Fresenius Environmental Bulletin 25(3): 852-861.

[23] Tabatabai, M.A., Brenner, J.M. (1970): Arylosulfatase activity of soils. - Soil Science Society of America Proccedings 34: 225-229.

[24] Vong, P.C., Dedourge, O., Guckert, A. (2004): Immobilization and mobilization of labelled sulphur in relation to soil arylsulphatase activity in rhizosphere soil of field-grown rape, barley and fallow. - Plant Soil 258: 227-239. doi: 10.1023/B:PLSO.0000016553,49882,9e 